\title{
Tank Mix of Saflufenacil with Glyphosate and Pendimethalin for Broad-spectrum Weed Control in Florida Citrus
}

\author{
Megh Singh, Mayank Malik, Analiza H.M. Ramirez, \\ and Amit J. Jhala ${ }^{1}$
}

ADDITIONAL INDEX WORDs. broadleaf weeds, grass weeds, herbicides, percent control, postemergence

Summary. Citrus (Citrus spp.) is one of the most important crops in Florida agriculture. Weed control is a major component in citrus production practices. If not controlled, weeds may compete with citrus trees for nutrients, water, and light and may also increase pest problems. Herbicides are an important component of integrated weed management program in citrus. Saflufenacil, a new herbicide registered for broadleaf weed control in citrus, can be applied alone or in a tank mix with other herbicides to improve weed control efficacy. A total of six field experiments were conducted in 2008 and 2009 to evaluate the efficacy of saflufenacil applied alone or in a tank mix with glyphosate and pendimethalin for weed control. In addition, experiments were also conducted to evaluate phytotoxicity of saflufenacil applied at different rates and time intervals in citrus. The results suggested that saflufenacil applied alone was usually effective for early season broadleaf weed control; however, weed control efficacy reduced beyond $\mathbf{3 0}$ days after treatment (DAT) compared with a tank mix of saflufenacil, glyphosate, and pendimethalin. For example, control of weeds was $\leq 70 \%$ when saflufenacil or glyphosate applied alone compared with tank mix treatments at 60 and 90 DAT. Addition of pendimethalin as a tank mix partner usually resulted in better residual weed control compared with a tank mix of saflufenacil and glyphosate, and this herbicide mixture was comparable with grower's adopted standard treatment of a tank mix of glyphosate, norflurazon, and diuron and several other tank mix treatments. Saflufenacil applied once in a season at different rates or even in sequential applications did not injure citrus trees when applied according to label directions. It is concluded that with its novel mode of action, saflufenacil tank mixed with glyphosate and pendimethalin would provide citrus growers with another chemical tool to control broadleaf and grass weeds.

$\mathrm{F}$ lorida is the largest producer of citrus including grapefruit (Citrus paradisi), sweet orange (Citrus sinensis), mandarin (Citrus reticulata), and mandarin hybrid cultivars in the United States and the second largest in the world (following Brazil) [U.S. Department of Agriculture (USDA), 2006]. In 2010, citrus was grown on more than 550,000 acres in Florida (USDA, 2010a) with the production of over 159 million boxes, which accounted for about $65 \%$ of the total U.S. production (USDA, 2010b). Florida citrus industry is the main economic force in the state. Total estimated economic impact of the citrus industry in the 2003-04 was $\$ 9.3$ billion in Florida's economy, and it is

Citrus Research and Education Center Institute of Food and Agricultural Sciences, University of Florida, 700 Experiment Station Road, Lake Alfred, FL 338502299

${ }^{1}$ Corresponding author. E-mail: amit@ufl.edu. estimated that by 2020 , it will be $\$ 10.8$ billion (Spreen et al., 2006).

Because of warm weather and frequent rainfall, weed management is an annual challenge for citrus growers in Florida to reduce weed competition as well as minimize weed interference with horticultural operations (Futch and Singh, 2007). Weed competition is damaging to citrus trees, especially when they are young, because it slows the tree growth and increases susceptibility to insects and diseases (Rogers et al., 2006). Weeds around tree trunks may create a favorable environment for pathogens that infect the trunk and roots (Futch and Singh, 2010). Direct reduction in tree growth and yield may occur when weed infestation is very dense; however, not all the weeds compete with citrus trees in the same level of competition.

Weed management in citrus groves greatly varies depending on the type of crop, producer, location, and availability of resources. Citrus growers use a combination of mechanical, chemical, and cultural methods to control weeds. Among various methods of weed control, herbicides are an important choice commonly used by citrus growers either as strip applications within the crop row or as broadcast applications to the grove floor (Sharma et al., 2008). Nonbearing young citrus trees $(<4$ years old) require greater attention to herbicide selection and application rates because the area around the tree is more exposed to sunlight and have greater weed pressure compared with older trees (Futch and Singh, 2000). Because of its broad weed spectrum, relatively low cost, and favorable environmental profile, glyphosate is used extensively in Florida citrus crops (Sharma and Singh, 2007). Although glyphosate is a broad-spectrum herbicide, not all weeds are equally susceptible to it (Culpepper and York, 2000). For example, barnyardgrass (Echinochloa crusgalli) is more sensitive to glyphosate compared with velvetleaf (Abutilon theophrasti) (Taylor, 1996).

Overreliance on a single herbicide could result in loss of effectiveness because of selection pressure, which results in evolution of herbicide-resistant weeds (Powles, 2008). Glyphosate is the dominant herbicide used extensively in many countries for many years (Duke and Powles, 2008). The occurrence of weed shifts and selection of glyphosateresistant biotypes in the United States and many other countries led to an

\begin{tabular}{llll}
\hline $\begin{array}{l}\text { Units } \\
\begin{array}{l}\text { To convert U.S. to SI, } \\
\text { multiply by }\end{array}\end{array}$ & U.S. unit & SI unit & $\begin{array}{l}\text { To convert SI to U.S., } \\
\text { multiply by }\end{array}$ \\
\hline 0.4047 & $\mathrm{acre}(\mathrm{s})$ & $\mathrm{ha}$ & 2.4711 \\
0.3048 & $\mathrm{ft}$ & $\mathrm{m}$ & 3.2808 \\
9.3540 & gal/acre & $\mathrm{L} \cdot \mathrm{ha}^{-1}$ & 0.1069 \\
2.54 & inch $(\mathrm{es})$ & $\mathrm{cm}$ & 0.3937 \\
0.1198 & $\mathrm{lb} / 100 \mathrm{gal}$ & $\mathrm{kg} / 100 \mathrm{~L}$ & 8.3454 \\
1.1209 & $\mathrm{lb} / \mathrm{acre}$ & $\mathrm{kg} \cdot \mathrm{ha}^{-1}$ & 0.8922 \\
70.0532 & $\mathrm{oz} / \mathrm{acre}$ & $\mathrm{g} \cdot \mathrm{ha}^{-1}$ & 0.0143 \\
6.8948 & $\mathrm{psi}$ & $\mathrm{kPa}$ & 0.1450
\end{tabular}


increased need for alternative herbicide programs including tank mix of herbicides with different mode of action (Beckie, 2006). Currently, 21 weed species have evolved resistance to glyphosate worldwide (Heap, 2011); however, there is no confirmed report of glyphosate-resistant weed in Florida citrus. Therefore, a strategy is required to avoid the glyphosate-resistant weeds in Florida citrus by identifying new herbicide chemistry with a different mode of action. Fortunately, a few new herbicides are in the process of registration or have recently been registered for weed control in citrus. For example, saflufenacil, commercially known as Treevix ${ }^{\mathrm{TM}}$ (BASF Corp., Research Triangle Park, NC) is a new postemergence, contact herbicide for broadleaf weed control in bearing and nonbearing citrus fruit trees (BASF Corp., $2010 \mathrm{c})$. Saflufenacil is also registered as Sharpen ${ }^{\mathrm{TM}}$ (BASF Corp.) for broadleaf weed control in chickpea (Cicer arietinum), maize (Zea mays), cotton (Gossypium hirsutum), soybean (Glycine max), and some other crops (BASF Corp., 2010b).

Saflufenacil is a uracil-based herbicide, which is a potent inhibitor of protoporphyrinogen oxidase [PPO (also known as protox)] (Grossman et al., 2010). The PPO-inhibiting herbicides competitively inhibit PPO by occupying the binding site for Protogen IX (Duke et al., 1991), which results in a rapid loss of membrane integrity and tissue necrosis and death of plant. Saflufenacil is translocated mainly in the xylem with limited mobility in the phloem (Liebl et al., 2008). It is readily absorbed by plant roots, shoots, and leaves. The injury symptoms on susceptible broadleaf species appear within a few hours, and plant die generally within 1 to $3 \mathrm{~d}$ under normal application and environmental conditions (Liebl et al., 2008). Saflufenacil is applied at relatively low rates. The label rate of saflufenacil applied as a postemergence in citrus is 1 $\mathrm{Oz} / \mathrm{acre}$ plus the recommended adjuvant in a single application with a maximum cumulative annual amount of $3 \mathrm{oz} /$ acre (BASF Corp., 2010c). It can be applied as a single application or sequentially up to three times per year. If applied sequentially, it must be separated by at least $21 \mathrm{~d}$ (BASF Corp., 2010c).

A tank mix of herbicides with different mode of action is one of the methods to reduce herbicide rates while maintaining weed control at acceptable levels (Green, 1991) and controlling herbicide-resistant weeds (Beckie, 2006). Saflufenacil is a broadleaf herbicide; therefore, it must be tank mixed with a grass herbicide or a broad-spectrum herbicide such as glyphosate for better weed control program. Saflufenacil has been tank mixed with dimethenamid$\mathrm{P}$ and registered as Verdict ${ }^{\mathrm{TM}}$ (BASF Corp.) for preemergence control of annual grasses, broadleaf weeds, and sedges in maize, grain sorghum (Sorghum bicolor), and soybean (BASF Corp., 2010d). Saflufenacil has also been tank mixed with imazethapyr and registered as Optil ${ }^{\mathrm{TM}}$ (BASF Corp.) for use in imidazolinone-resistant maize, soybean, and field pea (Pisum sativum) (BASF Corp., 2010a).

Pendimethalin (Prowl $\mathrm{H}_{2} \mathrm{O}^{\mathrm{TM}}$, BASF Corp.) is a preemergence, residual herbicide registered for control of annual grasses and some broadleaf weeds in Florida citrus (BASF Corp., 2009), but it is less effective on sedges and some hard-to-control broadleaf weeds such as shepherd's-purse (Capsella bursa-pastoris) and spreading dayflower (Commelina diffusa) (personal observation). Weed control spectrum of pendimethalin can be expanded by tank mixing with other residual herbicides such as diuron; for controlling existing weeds, it can be tank mixed with glyphosate or paraquat (BASF Corp., 2009). It is expected that when saflufenacil would be tank mixed with a postemergence herbicide such as glyphosate and a residual herbicide such as pendimethalin, the combination will provide control of existing weeds as well as extended residual weed control in Florida citrus. This tank mixture could also be effective for control of herbicide-resistant weeds. For example, Owen et al. (2011) reported $94 \%$ control of glyphosate-resistant horseweed (Conyza canadensis) with the application of saflufenacil before planting cotton.

There is no information available on weed control with tank mixes of saflufenacil, glyphosate, and pendimethalin at different rate combinations in Florida citrus. Therefore, the objectives of this study were 1) to evaluate the efficacy of saflufenacil applied alone and tank mix of saflufenacil, glyphosate, and/or pendimethalin at various rates for weed control in established citrus groves and 2) to evaluate the phytotoxicity of saflufenacil on citrus trees.

\section{Materials and methods}

2008. Two field experiments were conducted in a citrus grove at Polk City, FL, in 2008 to evaluate the efficacy of saflufenacil applied alone or in a tank mix with glyphosate and pendimethalin for weed control. The soil of the experimental site was Florida Candler fine sand (hyperthermic, uncoated, Typic Quartzipsamment). The experiments were laid-out in a randomized complete block design with four replications. The details of herbicide treatments applied in Expts. 1 and 2 are listed in Tables 1 and 2, respectively. All herbicide treatments were applied using a tractor-mounted computerized boom sprayer fitted with 8002 Teejet nozzles (Spraying System Co., Wheaton, IL) and an off center OC-4 flat spray tip, delivering $20 \mathrm{gal} / \mathrm{acre}$ spray volume at $30 \mathrm{psi}$. The plot size was $3 \times 18 \mathrm{~m}$, covering five citrus trees per plot. The trees were 3 years old when herbicides were applied. The herbicide treatments in both the experiments were applied on 25 June 2008 when weeds were about 10 to $15 \mathrm{~cm}$ tall. All herbicide treatments included ammonium sulfate applied at $2.03 \mathrm{~kg} /$ $100 \mathrm{~L}$ solution and crop oil concentrate at $1 \% \mathrm{v} / \mathrm{v}$. Visual percent control of grass and broadleaf weeds was recorded at $7,15,30,60$, and 90 DAT on a scale $0 \%$ to $100 \%$, where $0 \%$ being no control and $100 \%$ being complete control of all weeds at the time of observation compared with untreated control. Phytotoxicity of herbicide treatments on citrus trees was also evaluated based on a $0 \%$ to $100 \%$ scale, where $0 \%$ being no injury and $100 \%$ being complete death of the citrus tree.

Two field experiments were conducted at Haines City, FL, and Dundee, FL, in 2008 to evaluate phytotoxicity of saflufenacil applied alone or in a tank mix with glyphosate in young citrus trees. The treatments included glyphosate (Roundup Weathermax ${ }^{\mathrm{TM}}$; Monsanto, St. Louis, MO) applied alone at $2.25 \mathrm{lb} /$ acre, saflufenacil applied alone at 2 or $4 \mathrm{oz} /$ acre or in a sequential application after 2 months, and saflufenacil at $2 \mathrm{oz} /$ acre tank mixed with glyphosate at $2 \mathrm{lb} /$ acre. The experimental design was a randomized complete block with four replications. The herbicide treatments were manually applied with a knap sack sprayer at 
Table 1. Effects of herbicide treatments on control of grass and broadleaf weeds in Expt. 1 conducted at Polk City, FL, in 2008.

\begin{tabular}{|c|c|c|c|c|c|c|c|c|c|c|}
\hline \multirow[b]{2}{*}{ Herbicide treatment $^{\mathrm{z}}$} & \multicolumn{5}{|c|}{ Grass weeds (\% control $)^{\mathrm{y}}$} & \multicolumn{5}{|c|}{ Broadleaf weeds ( $\%$ control $)^{\mathrm{y}}$} \\
\hline & 7 DAT $^{x}$ & 15 DAT & $30 \mathrm{DAT}$ & $60 \mathrm{DAT}$ & $90 \mathrm{DAT}$ & $7 \mathrm{DAT}$ & 15 DAT & 30 DAT & $60 \mathrm{DAT}$ & $90 \mathrm{DAT}$ \\
\hline Untreated control & $0 \mathrm{c}$ & $0 \mathrm{~d}$ & $0 \mathrm{~d}$ & $0 \mathrm{~d}$ & $0 \mathrm{e}$ & $0.0 \mathrm{c}$ & $0.0 \mathrm{e}$ & $0 \mathrm{c}$ & $0 \mathrm{~d}$ & $0 \mathrm{~d}$ \\
\hline Saflufenacil $1 \mathrm{oz} /$ acre & $74 \mathrm{ab}$ & $80 \mathrm{c}$ & $79 c$ & $60 c$ & $54 \mathrm{~d}$ & $70 \mathrm{bc}$ & $74 \mathrm{~d}$ & $81 \mathrm{~b}$ & $70 \mathrm{c}$ & $57 \mathrm{c}$ \\
\hline $\begin{array}{c}\text { Saflufenacil } 1 \mathrm{oz} / \text { acre }+ \\
\text { glyphosate } 1 \mathrm{lb} / \text { acre }\end{array}$ & 79 a & $89 \mathrm{~b}$ & $82 \mathrm{bc}$ & $76 \mathrm{~b}$ & $71 \mathrm{~b}$ & $75 \mathrm{ab}$ & $87 \mathrm{ab}$ & $91 \mathrm{a}$ & $77 \mathrm{c}$ & $70 \mathrm{~b}$ \\
\hline $\begin{array}{l}\text { Saflufenacil } 1 \mathrm{oz} / \text { acre }+ \\
\text { glyphosate } 1 \mathrm{lb} / \text { acre }+ \\
\text { pendimethalin } 160 \mathrm{oz} / \text { acre }\end{array}$ & $81 \mathrm{a}$ & $100 \mathrm{a}$ & $94 \mathrm{a}$ & 97 a & $94 \mathrm{a}$ & $79 \mathrm{ab}$ & $90 \mathrm{ab}$ & $96 a$ & $96 a$ & $91 \mathrm{a}$ \\
\hline $\begin{array}{l}\text { Saflufenacil } 1 \mathrm{oz} / \text { acre }+ \\
\text { glyphosate } 1 \mathrm{lb} / \text { acre }+ \\
\text { pendimethalin } 140 \mathrm{oz} / \text { acre }\end{array}$ & $79 \mathrm{a}$ & $99 \mathrm{a}$ & $91 \mathrm{ab}$ & $94 \mathrm{a}$ & $92 \mathrm{a}$ & $74 \mathrm{~b}$ & $87 \mathrm{ab}$ & $95 \mathrm{a}$ & $92 \mathrm{ab}$ & $90 \mathrm{a}$ \\
\hline
\end{tabular}

Table 2. Effects of herbicide treatments on control of grass and broadleaf weeds in Expt. 2 conducted at Polk City, FL, in 2008.

\begin{tabular}{|c|c|c|c|c|c|c|c|c|c|c|}
\hline \multirow[b]{2}{*}{ Herbicide treatment $^{\mathrm{z}}$} & \multicolumn{5}{|c|}{ Grass weeds ( $\%$ control $)^{\mathrm{y}}$} & \multicolumn{5}{|c|}{ Broadleaf weeds ( $\%$ control $)^{\mathrm{y}}$} \\
\hline & $7 \mathrm{DAT}^{\mathrm{x}}$ & $15 \mathrm{DAT}$ & $30 \mathrm{DAT}$ & $60 \mathrm{DAT}$ & $90 \mathrm{DAT}$ & $7 \mathrm{DAT}$ & $15 \mathrm{DAT}$ & 30 DAT & $60 \mathrm{DAT}$ & $90 \mathrm{DAT}$ \\
\hline Untreated control & $0 \mathrm{c}$ & $0 \mathrm{~d}$ & $0 \mathrm{~d}$ & $0 \mathrm{~d}$ & $0 \mathrm{e}$ & $0 \mathrm{e}$ & $0 \mathrm{e}$ & $0 \mathrm{~d}$ & $0 \mathrm{~d}$ & $0 \mathrm{~d}$ \\
\hline Saflufenacil $1 \mathrm{oz} /$ acre & $70 \mathrm{~b}$ & $79 \mathrm{~b}$ & $75 \mathrm{c}$ & $65 \mathrm{c}$ & $59 \mathrm{~d}$ & $70 \mathrm{~cd}$ & $77 \mathrm{c}$ & $77 \mathrm{c}$ & $69 c$ & $60 \mathrm{c}$ \\
\hline $\begin{array}{c}\text { Saflufenacil } 1 \mathrm{oz} / \text { acre }+ \\
\text { glyphosate } 1 \mathrm{lb} / \text { acre }\end{array}$ & $77 \mathrm{ab}$ & $87 \mathrm{ab}$ & $87 \mathrm{~b}$ & $82 \mathrm{~b}$ & $79 \mathrm{~b}$ & $74 \mathrm{bcd}$ & $86 \mathrm{ab}$ & $85 \mathrm{~b}$ & $79 \mathrm{~b}$ & $74 \mathrm{~b}$ \\
\hline $\begin{array}{l}\text { Saflufenacil } 2 \mathrm{oz} / \text { acre }+ \\
\text { glyphosate } 1 \mathrm{lb} / \text { acre }\end{array}$ & $81 \mathrm{ab}$ & $87 \mathrm{ab}$ & $94 \mathrm{ab}$ & $81 \mathrm{~b}$ & $76 \mathrm{bc}$ & $77 \mathrm{abc}$ & $87 \mathrm{ab}$ & $91 \mathrm{a}$ & $81 \mathrm{~b}$ & $67 \mathrm{bc}$ \\
\hline $\begin{array}{l}\text { Saflufenacil } 1 \mathrm{oz} / \text { acre }+ \\
\text { glyphosate } 1 \mathrm{lb} / \text { acre }+ \\
\text { pendimethalin } 80 \mathrm{oz} / \text { acre }\end{array}$ & $82 \mathrm{a}$ & $92 \mathrm{a}$ & $96 a$ & $96 \mathrm{a}$ & $95 \mathrm{a}$ & $82 \mathrm{a}$ & $92 \mathrm{a}$ & $95 \mathrm{a}$ & $96 \mathrm{a}$ & $92 \mathrm{a}$ \\
\hline
\end{tabular}

$20 \mathrm{gal} / \mathrm{acre}$ spray volume at $30 \mathrm{psi}$. The plot size was $3 \times 15 \mathrm{~m}$, covering four trees per plot. The citrus trees were 2 years old when herbicides were sprayed. Treatments were applied at different time intervals on 29 Apr. 2008, 30 June 2008, and 29 Aug. 2008. All treatments included ammonium sulfate applied at $2.03 \mathrm{~kg} / 100 \mathrm{~L}$ solution and crop oil concentrate at $1 \% \mathrm{v} /$ v. Citrus injury was visually estimated at 7,15 , and $30 \mathrm{DAT}$ using the procedure described in the previous experiment.
2009. A field experiment was conducted in a grapefruit grove at Frostproof, FL, to evaluate efficacy of saflufenacil applied alone or in a tank mix for controlling weeds. Soil type was same as explained in 2008 study. The treatment detail is presented in Tables 3 and 4 . The herbicide applications were made on 1 May 2009. The adjuvants methylated seed oil $(1 \% \mathrm{v} / \mathrm{v})$ and ammonium sulfate $(2.03 \mathrm{~kg} / 100$ L) was added to all herbicide treatments. The grapefruit trees were 3 years old at the time of herbicide application.
The applications were made using a tractor mounted sprayer as explained in previous experiment. Visual percent control of weed species and potential injury on citrus was evaluated at $15,30,45,60$, and 90 DAT as per the procedure explained in previous experiments.

A field experiment was conducted in a citrus grove at the Citrus Research and Education Center, University of Florida, Lake Alfred. The citrus crop was 'Valencia' sweet orange. The treatment detail is presented in Tables 5 and 6 . 
Table 3. Effects of herbicide treatments on control of texas panicum at 15, 30, 45, 60, and $90 \mathrm{~d}$ after treatment (DAT) at Frostproof, FL, in 2009.

\begin{tabular}{|c|c|c|c|c|c|}
\hline \multirow[b]{2}{*}{ Herbicide treatment $^{\mathrm{z}}$} & 15 DAT & $30 \mathrm{DAT}$ & 45 DAT & 60 DAT & $90 \mathrm{DAT}$ \\
\hline & \multicolumn{5}{|c|}{$\%$ control $^{\mathrm{y}}$} \\
\hline Untreated control & $0 \mathrm{c}$ & $0 \mathrm{~d}$ & $0 \mathrm{~d}$ & $0 \mathrm{~d}$ & $0 \mathrm{c}$ \\
\hline Glyphosate $1.5 \mathrm{lb} /$ acre & $76 \mathrm{a}$ & $79 \mathrm{ab}$ & $77 \mathrm{~b}$ & $75 \mathrm{~b}$ & $20 \mathrm{~b}$ \\
\hline Saflufenacil $1 \mathrm{oz} /$ acre & $30 \mathrm{~b}$ & $43 \mathrm{c}$ & $7 \mathrm{c}$ & $3 c$ & $0 \mathrm{c}$ \\
\hline $\begin{array}{l}\text { Saflufenacil } 1 \mathrm{oz} / \text { acre }+ \\
\text { glyphosate } 1.5 \mathrm{lb} / \text { acre }\end{array}$ & $78 \mathrm{a}$ & $76 \mathrm{~b}$ & $75 \mathrm{~b}$ & $77 \mathrm{~b}$ & $28 \mathrm{~b}$ \\
\hline Saflufenacil $2 \mathrm{oz} /$ acre & $30 \mathrm{~b}$ & $42 \mathrm{c}$ & $8 \mathrm{c}$ & $7 \mathrm{c}$ & $7 \mathrm{c}$ \\
\hline $\begin{array}{l}\text { Saflufenacil } 2 \mathrm{oz} / \text { acre }+ \\
\text { glyphosate } 1.5 \mathrm{lb} / \text { acre }\end{array}$ & 81 a & $76 \mathrm{~b}$ & $80 \mathrm{~b}$ & $78 \mathrm{~b}$ & $33 \mathrm{~b}$ \\
\hline Saflufenacil $3 \mathrm{oz} /$ acre & $16 \mathrm{~b}$ & $35 \mathrm{c}$ & $12 \mathrm{c}$ & $7 \mathrm{c}$ & $10 \mathrm{bc}$ \\
\hline $\begin{array}{l}\text { Saflufenacil } 3 \mathrm{oz} / \text { acre }+ \\
\text { glyphosate } 1.5 \mathrm{lb} / \text { acre }\end{array}$ & $85 \mathrm{a}$ & $81 \mathrm{a}$ & $77 \mathrm{~b}$ & $77 \mathrm{~b}$ & $32 \mathrm{~b}$ \\
\hline $\begin{array}{l}\text { Saflufenacil } 2 \mathrm{oz} / \text { acre }+ \\
\text { glyphosate } 1.5 \mathrm{lb} / \text { acre }+ \\
\text { pendimethalin } 112 \mathrm{oz} / \text { acre }\end{array}$ & 89 a & $86 \mathrm{a}$ & 90 a & 88 a & 88 a \\
\hline $\begin{array}{l}\text { Saflufenacil } 3 \mathrm{oz} / \text { acre }+ \\
\text { glyphosate } 1.5 \mathrm{lb} / \text { acre }+ \\
\text { pendimethalin } 112 \mathrm{oz} / \text { acre }\end{array}$ & 88 a & 88 a & 90 a & 88 a & 83 a \\
\hline $\begin{array}{l}\text { Saflufenacil } 1 \mathrm{oz} / \text { acre }+ \\
\text { glyphosate } 0.75 \mathrm{lb} / \text { acre }+ \\
\text { pendimethalin } 112 \mathrm{oz} / \text { acre } \\
\end{array}$ & 88 a & 85 a & 93 a & 85 a & 85 a \\
\hline
\end{tabular}

Herbicide applications were made on 28 Apr. 2009 as explained in previous study. The nonionic surfactant (Induce at $0.25 \% \mathrm{v} / \mathrm{v}$ ) and ammonium sulfate at $2.03 \mathrm{~kg} / 100 \mathrm{~L}$ solution were included in herbicide treatments. The sweet orange trees were 3 years old at the time of herbicide application. Herbicide applications were made using a tractor mounted sprayer as explained in previous experiment. The visual percent control of weed species and potential injury on citrus was evaluated at $14,28,42$, and 86 DAT on the basis of the procedure explained in previous experiments.

Statistical analysis. The data from each field experiment was analyzed separately. All data were subjected to analysis of variance (ANOVA), and means were separated using Fisher's protected least significant difference (LSD) test $(P=0.05)$ in SAS (version 9.2; SAS Institute, Cary, NC). When the ANOVA revealed no significant treatment-by-location interaction for the Hanes and Dundee experimental sites in 2008 , data were pooled over locations for analysis. The data of percent weed control were arcsine transformed before analysis; however, nontransformed percentages are
Pendimethalin is used as a preemergence herbicide for control of grass and small-seeded dicot weed species; however, it can be tank mixed with other herbicide(s) to improve efficacy (BASF Corp., 2009). In the treatments that included pendimethalin as a tank mix partner, control of grass weeds was comparable with a tank mix of glyphosate, norflurazon, and diuron at 15 , 30,60 , and 90 DAT (Table 1). Similar to this result, a tank mix of pendimethalin and glyphosate provided 95\% control of witchgrass (Panicum capillare) and yellow foxtail (Setaria pumila) compared with glyphosate applied alone at 45 DAT in glyphosate-resistant alfalfa (Medicago sativa) (Affeldt and Rice, 2008).

The major broadleaf weeds infesting the Expt. I at Polk City, FL, were florida/brazil pusley (Richardia spp.), dayflower, and black nightshade (Solanum nigrum). The visual control ratings were combined for all the broadleaf species and presented as total broadleaf species controlled. Compared with untreated control, all the treatments were significantly effective for controlling broadleaf weeds at $15,30,60$, and 90 DAT (Table 1). Although the difference was nonsignificant with some other treatments, maximum control of broadleaf weeds $(82 \%)$ was obtained with grower's practice of using a tank mix of norflurazon, diuron, and glyphosate at 7 DAT. On the other hand, a tank mix of saflufenacil, glyphosate, and pendimethalin was as effective as a tank mix of norflurazon, diuron, and glyphosate at 30,60, and 90 DAT (Table 1). In an experiment conducted for weed control in glyphosate-resistant alfalfa, a tank mix of pendimethalin and glyphosate provided $100 \%$ control of horseweed compared with a tank mix of pendimethalin with imazamox $(25 \%$ control) or $2,4-\mathrm{DB}(45 \%$ control $)$ at 45 DAT (Affeldt and Rice, 2008). Glyphosate tank mixed with pendimethalin provided long-term control of grass weeds; however, addition of saflufenacil provided better broadleaf weed control. The tank mix of pendimethalin at all the rates was equally effective.

Grass and broadleaf weed species present in Expt. 2 at Polk City, FL, were the same as in Expt. 1 in 2008. All treatments were effective for reducing grass weed populations compared with untreated control (Table 2). A tank mix of saflufenacil with glyphosate 


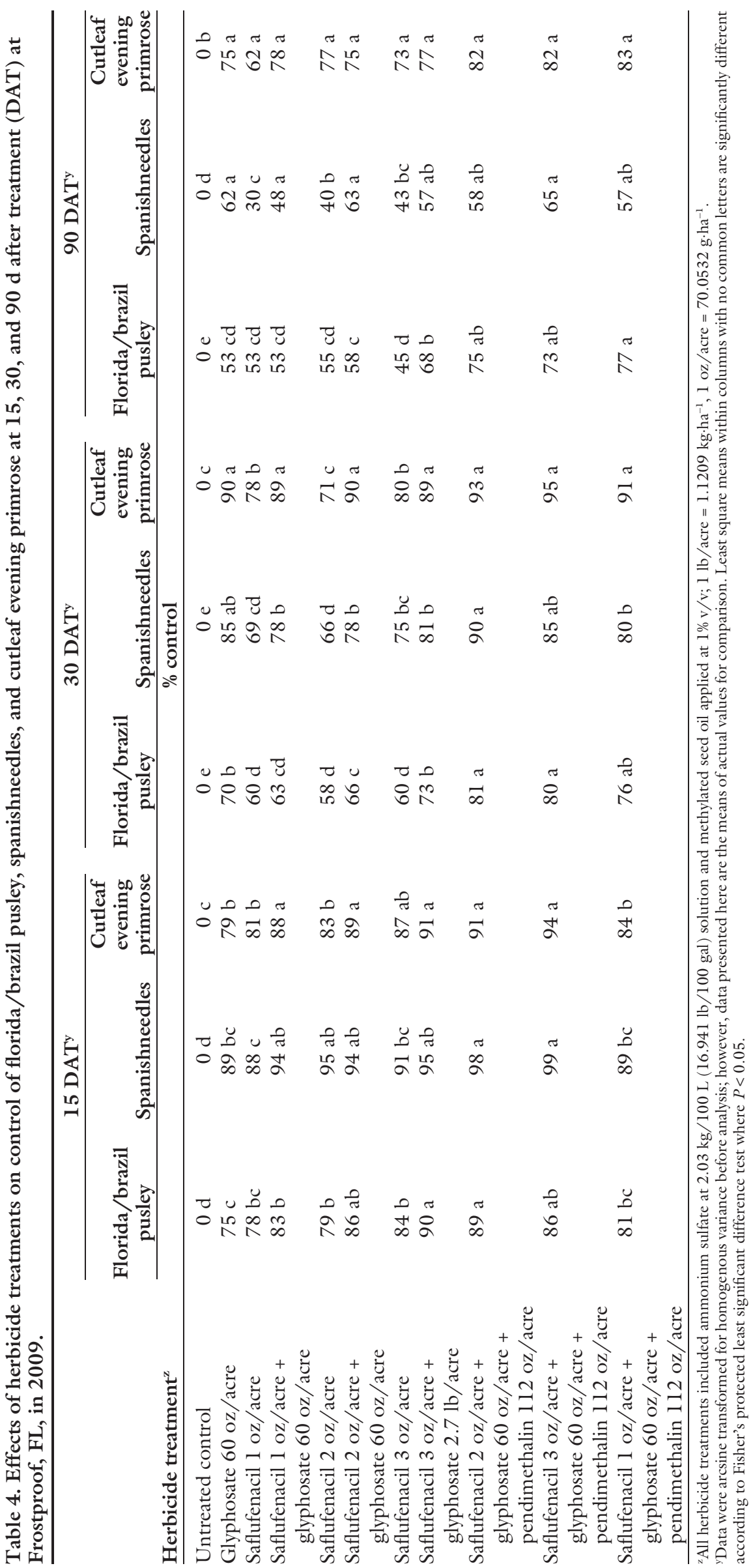

and pendimethalin provided $82 \%$ control of grass weeds at 7 DAT; however, it was not significantly different from other tank mix treatments. Percent control of grass weeds increased gradually with all herbicide treatments at $30 \mathrm{DAT}$, and thereafter control was reduced slightly with the treatments where pendimethalin was not added in the tank mix. The application of glyphosate alone provided significantly higher percent control of grass weeds compared with saflufenacil applied alone at 30,60 , and $90 \mathrm{DAT}$ (Table 2). This might be due to the mode of action of saflufenacil as it is primarily a dicot herbicide; therefore, it is not much effective on monocot species (BASF Corp., 2010c). For example, experiments conducted to evaluate winter wheat (Triticum aestipum) response to postemergence application of saflufenacil suggested that wheat foliar necrosis was $<15 \%$ at 10 to 20 DAT and was not evident at 30 DAT (Frihauf et al., 2010). A tank mix of saflufenacil and glyphosate provided similar control of grass weeds compared with a tank mix of saflufenacil, glyphosate, and pendimethalin at $30 \mathrm{DAT}$. However, a tank mix of saflufenacil with glyphosate provided inferior grass control compared with a tank mix of saflufenacil, glyphosate, and pendimethalin at 60 and 90 DAT (Table 2). Therefore, addition of pendimethalin was very effective to provide residual grass weed control.

All herbicide treatments were effective for controlling broadleaf weeds in all the visual ratings compared with untreated control (Table 2). Percent control of broadleaf weeds was similar when glyphosate or saflufenacil was applied alone. A tank mix of saflufenacil with glyphosate provided significantly better control of broadleaf weeds compared with saflufenacil applied alone at $15,30,60$, and 90 DAT. At 15 and 30 DAT, a tank mix of saflufenacil, glyphosate, and pendimethalin and a tank mix of glyphosate and pendimethalin provided similar control of broadleaf weeds compared with a tank mix of saflufenacil and glyphosate. Control of broadleaf weeds reduced gradually after 30 DAT in the treatments where pendimethalin was not included in a tank mix. For example, at 60 and 90 DAT, significantly higher control of broadleaf weeds was obtained in the treatments where pendimethalin was tank mixed with glyphosate or with 
Table 5. Effects of herbicide treatments on control of florida/brazil pusley, common purslane, and dogfennel at 14 , 42, and $86 \mathrm{~d}$ after treatment (DAT) at Lake Alfred, FL, in 2009.

\begin{tabular}{|c|c|c|c|c|c|c|c|c|c|}
\hline \multirow{2}{*}{ Herbicide treatment $^{\mathrm{z}}$} & \multicolumn{3}{|c|}{$14 \mathrm{DAT}^{\mathrm{y}}$} & \multicolumn{3}{|c|}{$42 \mathrm{DAT}^{\mathrm{y}}$} & \multicolumn{3}{|c|}{$86 \mathrm{DAT}^{\mathrm{y}}$} \\
\hline & $\begin{array}{l}\text { Florida/ } \\
\text { brazil } \\
\text { pusley }\end{array}$ & $\begin{array}{l}\text { Common } \\
\text { purslane }\end{array}$ & Dogfennel & $\begin{array}{l}\text { Florida/ } \\
\text { brazil } \\
\text { pusley }\end{array}$ & $\begin{array}{l}\text { Common } \\
\text { purslane }\end{array}$ & Dogfennel & $\begin{array}{l}\text { Florida/ } \\
\text { brazil } \\
\text { pusley }\end{array}$ & $\begin{array}{l}\text { Common } \\
\text { purslane }\end{array}$ & Dogfennel \\
\hline Untreated control & $0 \mathrm{c}$ & $0 \mathrm{~d}$ & $0 \mathrm{e}$ & $0 \mathrm{f}$ & $0 \mathrm{~d}$ & $0 \mathrm{e}$ & $0 \mathrm{f}$ & $0 \mathrm{~d}$ & $0 \mathrm{f}$ \\
\hline Saflufenacil $1 \mathrm{oz} /$ acre & $55 \mathrm{ab}$ & $78 \mathrm{c}$ & $73 \mathrm{bc}$ & $44 \mathrm{e}$ & $71 \mathrm{c}$ & $75 \mathrm{~d}$ & $46 \mathrm{e}$ & $73 c$ & $68 \mathrm{e}$ \\
\hline $\begin{array}{l}\text { Saflufenacil } 1 \mathrm{oz} / \mathrm{acre}+ \\
\text { pendimethalin } \\
112 \mathrm{oz} / \text { acre }\end{array}$ & $59 \mathrm{ab}$ & $93 \mathrm{ab}$ & $64 c$ & $74 \mathrm{bcd}$ & $80 \mathrm{abc}$ & 81 bcd & $65 \mathrm{bcd}$ & $76 \mathrm{abc}$ & $79 \mathrm{bc}$ \\
\hline Glufosinate $35 \mathrm{oz} /$ acre & $70 \mathrm{a}$ & $94 \mathrm{ab}$ & $80 \mathrm{ab}$ & $75 \mathrm{abcd}$ & $74 \mathrm{bc}$ & $80 \mathrm{~cd}$ & $64 \mathrm{~cd}$ & $76 \mathrm{abc}$ & $75 \mathrm{~cd}$ \\
\hline Paraquat $1 \mathrm{lb} /$ acre & $65 \mathrm{a}$ & $99 \mathrm{a}$ & $89 a$ & $81 \mathrm{ab}$ & $85 \mathrm{a}$ & $89 \mathrm{a}$ & $76 \mathrm{ab}$ & $81 \mathrm{ab}$ & $81 \mathrm{ab}$ \\
\hline Glyphosate $40 \mathrm{oz} /$ acre & $54 \mathrm{ab}$ & $91 \mathrm{ab}$ & $81 \mathrm{ab}$ & $79 \mathrm{abc}$ & $84 \mathrm{a}$ & $84 \mathrm{abc}$ & $65 \mathrm{bcd}$ & $76 \mathrm{abc}$ & $76 \mathrm{bcd}$ \\
\hline $\begin{array}{l}\text { Glyphosate } 40 \mathrm{oz} / \text { acre }+ \\
\text { trifloxysulfuron-sodium } \\
0.2 \mathrm{oz} / \text { acre }\end{array}$ & $51 \mathrm{ab}$ & $94 \mathrm{ab}$ & $71 \mathrm{bc}$ & $69 \mathrm{~d}$ & $80 \mathrm{abc}$ & $84 \mathrm{abc}$ & $71 \mathrm{abc}$ & $79 \mathrm{abc}$ & $81 \mathrm{ab}$ \\
\hline $\begin{array}{l}\text { Glyphosate } 40 \mathrm{oz} / \text { acre }+ \\
\text { trifloxysulfuron-sodium } \\
0.4 \mathrm{oz} / \text { acre }\end{array}$ & $65 \mathrm{a}$ & $91 \mathrm{ab}$ & $83 \mathrm{ab}$ & $76 \mathrm{abcd}$ & $80 \mathrm{abc}$ & $88 \mathrm{ab}$ & $71 \mathrm{abc}$ & $79 \mathrm{abc}$ & $79 \mathrm{bc}$ \\
\hline $\begin{array}{l}\text { Glyphosate } 40 \mathrm{oz} / \text { acre }+ \\
\text { simazine } 1 \mathrm{lb} / \text { acre }\end{array}$ & $58 \mathrm{ab}$ & $94 \mathrm{ab}$ & $85 \mathrm{ab}$ & $80 \mathrm{abc}$ & $85 \mathrm{a}$ & $86 a b c$ & $68 \mathrm{abcd}$ & $79 \mathrm{abc}$ & $78 \mathrm{bcd}$ \\
\hline $\begin{array}{c}\text { Glyphosate } 40 \mathrm{oz} / \text { acre }+ \\
\text { simazine } 1 \mathrm{lb} / \text { acre }+ \\
\text { mesotrione } 3 \mathrm{oz} / \text { acre }\end{array}$ & $64 \mathrm{ab}$ & $93 \mathrm{ab}$ & $81 \mathrm{ab}$ & $84 \mathrm{a}$ & $81 \mathrm{ab}$ & $88 \mathrm{ab}$ & $78 \mathrm{a}$ & $83 a$ & $85 \mathrm{a}$ \\
\hline $\begin{array}{c}\text { Glyphosate } 40 \mathrm{oz} / \text { acre }+ \\
\text { norflurazon } 3.2 \mathrm{lb} / \text { acre }\end{array}$ & $65 \mathrm{a}$ & $95 \mathrm{ab}$ & $73 \mathrm{bc}$ & $80 \mathrm{abc}$ & $76 \mathrm{abc}$ & $88 \mathrm{ab}$ & $69 \mathrm{abc}$ & $76 \mathrm{abc}$ & $79 \mathrm{bc}$ \\
\hline
\end{tabular}

saflufenacil and glyphosate compared with the tank mix of saflufenacil plus glyphosate (Table 2 ). This might be because pendimethalin is primarily a residual grass herbicide; however, excellent broadleaf weed control with addition of pendimethalin in the tank mix indicates synergistic effect of other two herbicides on the efficacy of pendimethalin. A previous study suggested that saflufenacil with crop oil concentrate and saflufenacil tank mixed with 2,4-D amine controlled blue mustard (Chorispora tenella) $\geq 91 \%$ at 17 and 21 DAT compared with less than $50 \%$ control with 2,4-D amine applied alone (Frihauf et al., 2010).

There was no treatment by location interaction for the Hanes City, FL, and Dundee, FL, experimental sites to evaluate the injury of saflufenacil in citrus; therefore data were pooled over locations for analysis. There was no injury from a single or sequential application of saflufenacil applied at 2 or $4 \mathrm{oz} /$ acre on citrus trees at 7,15 , and 30 DAT (data not shown). The label rate of saflufenacil in citrus is 1 $\mathrm{oz} / \mathrm{acre}$, so citrus trees have provided 2 - to 4 -fold safety. This study demonstrated that saflufenacil with adjuvants used in this study can be a good option for broadleaf weed control in citrus groves without any injury on citrus trees (data not shown). By contrast, experiments conducted to determine the response of maize to postemergence application of saflufenacil suggested that addition of an adjuvant to saflufenacil caused $99 \%$ injury at three leaf stage and reduced yield up to $59 \%$ compared with saflufenacil applied without adjuvant (Soltani et al., 2009).

Overall results of the experiments conducted in 2008 suggested that application of saflufenacil alone was not effective for controlling grass weeds, but provided similar broadleaf weed control compared with glyphosate applied alone; however, a tank mix of saflufenacil with glyphosate usually increased weed control efficacy. Addition of pendimethalin into the tank mix of saflufenacil and glyphosate improved weed control by providing a longer residual activity similar to a tank mix of norflurazon, diuron, and glyphosate. There was no difference in control of grass and broadleaf weeds with the high rate of pendimethalin as a tank mix partner. Therefore, a lower rate of pendimethalin should be used when applied in a tank mix with saflufenacil and glyphosate to achieve sufficient weed control. There was no injury from any saflufenacil treatment applied alone even at higher rates up to $4 \mathrm{oz} /$ acre or in a tank mix with glyphosate or in a sequential application on citrus trees indicating its level of safety (data not shown). 


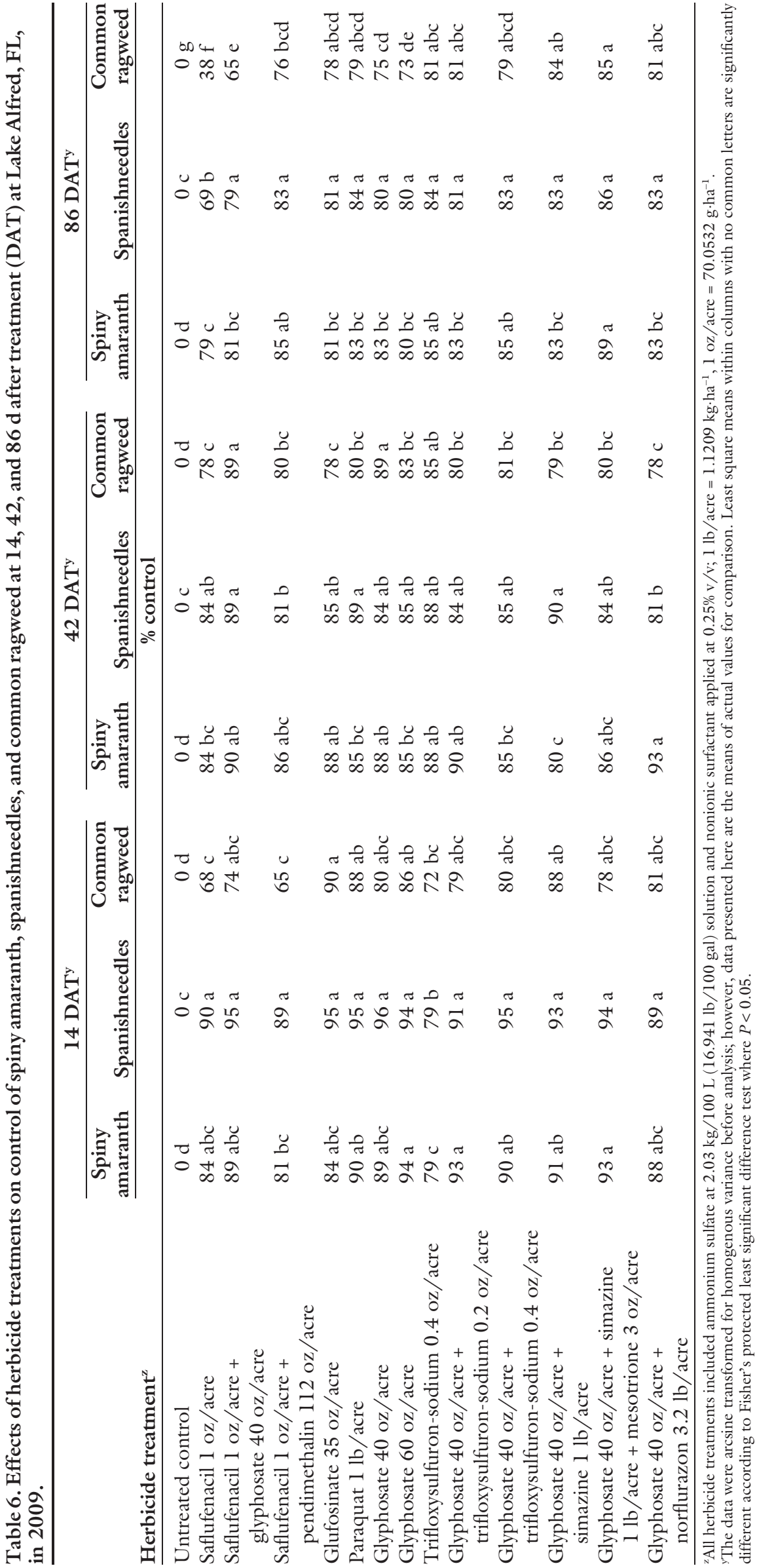

2009. The only grass weed present at the Frostproof, FL, experimental site was texas panicum. Visual weed control evaluations conducted at different time intervals suggested that all herbicide treatments were effective for controlling texas panicum compared with untreated control (Table 4). A tank mix of saflufenacil with glyphosate provided a greater control of texas panicum compared with saflufenacil applied alone. For example, control at 45,60 , and 90 DAT was $7 \%, 3 \%$, and $0 \%$, respectively, whereas a tank mix of glyphosate with saflufenacil provided $75 \%, 77 \%$, and $28 \%$ control, respectively (Table 3 ). The residual weed control of saflufenacil and glyphosate treatments started declining beyond 45 DAT. Later in the season (>30 DAT), a tank mix of saflufenacil, glyphosate, and pendimethalin provided significantly better control of texas panicum compared with other treatments. Control of texas panicum was $>82 \%$ at 90 DAT in a tank mix of saflufenacil, glyphosate, and pendimethalin indicated the effectiveness of pendimethalin as a tank mix partner (Table $3)$. Thus, this tank mix combination can provide a long-term weed control option to citrus growers.

The major broadleaf weeds at the Frostproof, FL, experimental site were florida/brazil pusley, spanishneedles (Bidens bipinnata), and cutleaf evening primrose (Oenothera laciniata). All herbicide treatments were effective for controlling broadleaf weeds compared with untreated control (Table 4). The application of saflufenacil alone at $\mathrm{l} \mathrm{oz} /$ acre provided similar control of florida/brazil pusley compared with a tank mix of saflufenacil and glyphosate at 15 and 30 DAT (Table 4). Knezevic et al. (2009) reported that saflufenacil applied at 1 to $2 \mathrm{oz} /$ acre was sufficient to control broadleaf weeds including field bindweed (Convolvulus arvensis), prickly lettuce (Lactuca serriola), henbit (Lamium amplexicaule), shepherd's-purse, dandelion ( Taraxacum officinale), and field pennycress (Thlaspi arvense). Control of spanishneedles and cutleaf evening primrose was significantly better in a tank mix treatments at 15 and 30 DAT compared with saflufenacil applied alone (Table 4). A tank mix of pendimethalin, saflufenacil, and glyphosate provided $81 \%$ to $99 \%$ control of all three broadleaf weeds at 15 DAT. The tank mix treatment that included pendimethalin 
controlled $76 \%$ to $95 \%$ broadleaf weeds at 30 DAT. Control of florida/brazil pusley and spanishneedles started declining at $45 \mathrm{DAT}$ (data not shown) and was minimal at 90 DAT when glyphosate or saflufenacil applied alone or in a tank mix (Table 4). A tank mix of saflufenacil, glyphosate, and pendimethalin provided long-term residual weed control. For example, control of florida/brazil pusley was $>72 \%$ at 90 DAT when pendimethalin was a tank mix partner. Although there was no significant difference with other tank mix treatments, control of cutleaf evening primrose was $>80 \%$ at 90 DAT with pendimethalin as a tank mix partner (Table 4). There was no injury on grapefruit from any of the treatments.

The only grass weed infesting the experimental site at Lake Alfred, FL, in 2009 was guineagrass. Saflufenacil applied alone provided only $5 \%$ to $40 \%$ control of guineagrass (data not shown). A tank mix of saflufenacil with glyphosate provided $88 \%$ and $84 \%$ control of guineagrass, respectively, at 14 and 28 DAT, whereas a tank mixes of saflufenacil with pendimethalin provided relatively less control of guineagrass at 14 and 28 DAT. Similarly, glufosinate and paraquat applied alone provided $70 \%$ and $65 \%$ control of guineagrass, respectively, at $14 \mathrm{DAT}$; however, the control was reduced to $58 \%$ at 86 DAT (data not shown). Glyphosate applied alone at higher rate provided $90 \%$ guineagrass control at 14 DAT compared with $60 \%$ control at 86 DAT (data not shown). Similarly, a tank mix of trifloxysulfuron with glyphosate provided $74 \%$ to $90 \%$ control of guineagrass compared with $48 \%$ to $66 \%$ control by trifloxysulfuron alone. A tank mix of glyphosate with simazine provided $60 \%$ to $90 \%$ control of guineagrass, and there was no additional control provided by addition of mesotrione in this treatment combination. When glyphosate was tank mixed with norflurazone, a consistent control of guineagrass ( $\geq 80 \%$ ) was observed throughout the growing season (data not shown). The residual control of saflufenacil and other herbicides applied alone or in a tank mix with glyphosate usually reduced efficacy beyond 56 DAT. Similarly, guineagrass control with postemergence herbicides such as glufosinate and paraquat started declining beyond 56 DAT (data not shown).

The major broadleaf weeds infesting the experimental site at Lake
Alfred, FL, included florida/brazil pusley, spanishneedles, common purslane (Portulaca oleracea), dogfennel (Eupatorium capillifolium), spiny amaranth (Amaranthusspinosus), and common ragweed (Ambrosia artemisiifolia). Results showed that all herbicide treatments provided significant control of broadleaf weeds compared with untreated control (Tables 5 and 6). A tank mix of saflufenacil with pendimethalin provided $59 \%, 93 \%$, and $65 \%$ control of florida/brazil pusley, purslane, and dogfennel, respectively, at 14 DAT. Similarly, saflufenacil alone and saflufenacil plus glyphosate provided similar control of these broadleaf weed species at 28 DAT (data not shown). A previous study reported that saflufenacil applied at $30 \mathrm{~g} \cdot \mathrm{ha}^{-1}(0.43 \mathrm{oz} / \mathrm{acre})$ reduced the density of blue mustard, flixweed (Descurainia sophia), palmer amaranth (Amaranthus palmeri), and tumble pigweed (Amaranthus albus) by $63 \%$ to $93 \%$ (Geier et al., 2009). A tank mix of pendimethalin and saflufenacil had $68 \%$ to $86 \%$ control of broadleaf weeds at $28 \mathrm{DAT}$. The reduced weed control in this treatment combination might be due to the weeds already present at the experimental site before herbicide applications. Similarly, broadleaf weed control with glufosinate and paraquat varied from $65 \%$ to $99 \%$ at 14 and 28 DAT (Table 5 ). The broadleaf weed control by glufosinate and paraquat applied alone was comparable to glyphosate and saflufenacil treatments. Similarly, trifloxysulfuron applied alone or tank mixed with glyphosate provided $43 \%$ to $65 \%$ control of florida/brazil pusley at 14 DAT; however, florida/brazil pusley control was improved at 28 DAT $(60 \%$ to $73 \%$ ) (data not shown) with trifloxysulfuron alone or in a tank mix with glyphosate (Table 5). The percent control of florida/brazil pusley and dogfennel was $71 \%$ and $81 \%$, respectively, with trifloxysulfuron applied alone or in a tank mix with glyphosate at $86 \mathrm{DAT}$. A study conducted to evaluate the effects of trifloxysulfuron on 12 weed species of citrus demonstrated various responses of weeds to this herbicide (Singh and Singh, 2004). The differential control by trifloxysulfuron-sodium could be attributed to differences in uptake, translocation, and metabolism in different species (Askew and Wilcut, 2002).

All herbicide treatments provided good control of spiny amaranth ranging from $79 \%$ to $95 \%$ compared with the untreated control (Table 6). Similarly, all the herbicide treatments provided $>79 \%$ control of spanishneedles up to 42 DAT. However, control of spanishneedles treated with saflufenacil alone declined to $69 \%$ at 86 DAT compared with other treatments ( $\mathrm{Ta}-$ ble 6). Surprisingly, control of common ragweed was relatively less in a tank mix of saflufenacil with pendimethalin at $14 \mathrm{DAT}$; however, later in the season, control of common ragweed improved in this treatment and provided $>76 \%$ control at 42 and 86 DAT (Table 6). The efficacy of saflufenacil applied alone declined by 86 DAT, and common ragweed control declined to 38\% (Table 6). Other herbicide treatments provided $65 \%$ to $85 \%$ common ragweed control at 86 DAT. The highest control of broadleaf species was obtained in a tank mix of saflufenacil with glyphosate and pendimethalin, and it was usually comparable with a tank mix of glyphosate plus simazine, glyphosate plus simazine plus mesotrione, and glyphosate plus norflurazon (Table 6). Weed species that are not effectively controlled by a single herbicide have shown increased occurrence in citrus groves and can be better controlled with a tank mix of herbicides. For example, a tank mix of glyphosate plus carfentrazone provided better control of florida/brazil pusley and dayflower compared with applied alone (Sharma et al., 2008).

With the exception of trifloxysulfuron-sodium, there was no injury of any herbicide treatment on 'Valencia' sweet orange trees (data not shown). The application of trifloxysulfuronsodium at higher rate caused some initial injury to citrus trees ( $5 \%$ to $9 \%$ ) (data not shown). However, those trees recovered later in the season, and no injury symptom was noticed at 86 DAT. Trifloxysulfuron-sodium is an acetolactate synthase inhibitor and belongs to the sulfonylurea group, which has been evaluated for weed control in cotton (Porterfield et al., 2003) and sugarcane (Saccharum officinarum) (Dally and Richard, 2008). Similar to this result, previous studies reported that cotton recovered from trifloxysulfuron injury within 3 to 6 weeks after treatment and caused no yield penalty (Barber et al., 2002; Porterfield et al., 2003).

Overall results of experiments conducted in 2009 suggested that a tank mix of saflufenacil, glyphosate, and 
pendimethalin provided similar weed control compared with several other tank mix herbicides including a tank mix of glyphosate and simazine, glyphosate plus simazine plus mesotrione, and glyphosate with norflurazon. Therefore, a tank mix herbicides with different mode of action will control problem weed species including herbicide-resistant weeds. Saflufenacil has been reported to be effective in controlling glyphosate-resistant weeds (Ashigh and Hall, 2010) such as glyphosate-resistant horseweed (Owen et al., 2011). Preliminary experiments conducted in California confirmed that saflufenacil is a strong performer on several winter annual broadleaf weeds, including glyphosate-resistant horseweed and hairy fleabane (Conyza bonariensis) in perennial crops (B. Hanson, personal communication).

\section{Conclusion}

Control of both broadleaf and grass weeds is necessary for successful establishment and growth of citrus trees. Saflufenacil is a broadleaf herbicide; therefore, for a broad-spectrum weed control, it needs to be tank mixed with other herbicide(s). In this study, saflufenacil was tank mixed with glyphosate and pendimethalin and compared with other tank mix herbicides for broadleaf and grass weed control in Florida citrus. This research reported that saflufenacil has a potential for providing broad-spectrum weed control in citrus when tank mixed with glyphosate and pendimethalin. There was no phytotoxic effect of saflufenacil on citrus trees in any experiment, which makes this herbicide safe to use. In addition, it is likely that this tank mix treatment could be effective for control of herbicide-resistant weeds. More research is required to evaluate the efficacy of saflufenacil tank mixed with other postemergence herbicides for weed control in citrus.

\section{Literature cited}

Affeldt, R. and C. Rice. 2008. Evaluation of pendimethalin (Prowl) tank mixes on Roundup Ready alfalfa. 12 May 2011. $<$ http://extension.oregonstate.edu/catalog/ html/sr/sr1093-e/sr1093_17.pdfs.

Ashigh, J. and J.C. Hall. 2010. Bases for interactions between saflufenacil and glyphosate in plants. J. Agr. Food Chem. 58:7335-7343.
Askew, S.D. and J.W. Wilcut. 2002. Absorption, translocation and metabolism of foliar-applied CGA-362622 in cotton, peanut, and selected weeds. Weed Sci. 50:293-298.

Barber, L.T., D.B. Reynolds, J.C. Sanders, D.G. Wilson, N.W. Buehring, and K.M. Bloodworth. 2002. Weed control with CGA-362622 in roundup ready and BXN cotton systems. Proc. Southern Weed Sci. Soc. 55:140. (Abstr.).

BASF Corp. 2008. Kixor ${ }^{\mathrm{TM}}$ herbicide worldwide. Worldwide technical brochure. BASF Corp., Research Triangle Park, NC.

BASF Corp. 2009. Prowl $\mathrm{H}_{2} \mathrm{O}^{\mathrm{TM}}$ herbicide label. BASF Corp., Research Triangle Park, NC.

BASF Corp. 2010a. Optil ${ }^{\mathrm{TM}}$ herbicide label. BASF Corp., Research Triangle Park, NC.

BASF Corp. 2010b. Sharpen ${ }^{\text {TM }}$ herbicide label. BASF Corp., Research Triangle Park, NC.

BASF Corp. 2010c. Treevix ${ }^{\mathrm{TM}}$ herbicide label. BASF Corp., Research Triangle Park, NC.

BASF Corp. 2010d. Verdict ${ }^{\mathrm{TM}}$ herbicide label. BASF Corp., Research Triangle Park, NC.

Beckie, H.J. 2006. Herbicide-resistant weeds: Management tactics and practices. Weed Technol. 20:793-814.

Culpepper, A.S. and A.C. York. 2000. Weed management in ultra narrow row cotton (Gossypium hirsutum). Weed Technol. 14:19-29.

Dally, C.D. and E.P. Richard. 2008. Control of rhizome johnsongrass (Sorghum halepense) in sugarcane with trifloxysulfuron and asulam. Weed Technol. 22:397-401.

Duke, S.O., J. Lydon, J.M. Becerril, T.D. Shernam, L.P. Lehnen, and H. Matsumoto. 1991. Protoporphyrinogen oxidaseinhibiting herbicides. Weed Sci. 39:465473.

Duke, S.O. and S.B. Powles. 2008. Glyphosate: A once in a century herbicide. Pest Mgt. Sci. 64:319-325.

Frihauf, J.C., P.W. Stahlman, P.W. Geier, and D.E. Peterson. 2010. Winter annual broadleaf weeds and wheat response to post-emergence application of two saflufenacil formulations. Weed Technol. 24:416-424.

Futch, S.H. and M. Singh. 2000. Field evaluation of chemical weed control in Florida citrus. Proc. Florida State Hort. Soc. 113:68-74.
Futch, S.H. and M. Singh. 2007. Weeds in Florida citrus-New challenges and opportunities. Citrus Ind. 88:15-17.

Futch, S.H. and M. Singh. 2010. Florida citrus pest management guide: Weeds, p. 125137. In: M.E. Rogers, M.M. Dewdney, and T.M. Spann (eds.). 2010 Florida citrus pest management guide. Inst. Food Arg. Sci., Univ. of Florida, Gainesville.

Geier, P.W., P.W. Stahlman, and L.D. Charvat. 2009. Dose responses of five broadleaf weeds to saflufenacil. Weed Technol. 23:313-316.

Green, J.M. 1991. Maximizing herbicide efficiency with mixtures and expert systems. Weed Technol. 5:894-897.

Grossman, K., R. Niggeweg, N. Christiansen, R. Looser, and T. Ehrhardt. 2010. The herbicide saflufenacil (Kixor ${ }^{\mathrm{TM}}$ ) is a new inhibitor of protoporphyrinogen IX oxidase activity. Weed Sci. 58:1-9.

Heap, I. 2011. International survey of herbicide resistant weeds. 5 May 2011. <http://www.weedscience.org/Summary/ UspeciesMOA.asp? 1stMOAID $=12 \& \mathrm{Fm}$ HRACGroup $=$ Go $>$.

Knezevic, S.Z., A. Datta, J. Scott, and L.D. Charvat. 2009. Adjuvants influenced saflufenacil efficacy on fall-emerging weeds. Weed Technol. 23:340-345.

Liebl, R.A., H. Walter, S.J. Bowe, T.J. Holt, and D.E. Westberg. 2008. BAS $800 \mathrm{H}$ : A new herbicide for preplant burndown and preemergence dicot weed control. Proc. Weed Sci. Soc. Amer. Annu. Conf. 48: 120. (Abstr.).

Owen, L.N., T.C. Mueller, C.L. Main, J.C. Bond, and L.E. Steckel. 2011. Evaluating rates and application timings of saflufenacil for control of glyphosateresistant horseweed (Conyza canadenis) prior to planting no-till cotton. Weed Technol. 25:1-5.

Porterfield, D., J.W. Wilcut, J.W. Wells, and S.B. Clewis. 2003. Weed management with CGA-362622 in transgenic and nontransgenic cotton. Weed Sci. 51:1002-1009.

Powles, S. 2008. Evolved glyphosateresistant weeds around the world: Lessons to be learnt. Pest Mgt. Sci. 64:360-365.

Rogers, M.E., L.W. Timmer, and S.H. Futch. 2006. Pesticides registered for use on Florida citrus, p. 123-146. In: M.E. Rogers and L.W. Timmer (eds.). 2006 Florida citrus pest management guide. Univ. of Florida, Coop. Ext. Serv., Inst. Food Agr. Sci. SP-43.

Singh, S. and M. Singh. 2004. Effect of growth stage on trifloxysulfuron and glyphosate efficacy in twelve weed species of citrus groves. Weed Technol. 18:1031-1036. 
Sharma, S.D. and M. Singh. 2007. Effect of timing and rates of application of glyphosate and carfentrazone herbicides and their mixtures on the control of some broadleaf weeds. HortScience 42:1221-1226.

Sharma, S.D., M. Singh, and S.H. Futch. 2008. Glyphosate and carfentrazone herbicides for difficult to control weeds in citrus. Proc. Florida State Hort. Soc. 121:1-5.

Soltani, N., C. Shropshire, and P.H. Sikkema. 2009. Response of corn to preemergence and postemergence applications of saflufenacil. Weed Technol. 23:331-334.
Spreen, T.H., R.E. Barber, M.G. Brown, A.W. Hodges, J.C. Malugen, W.D. Mulkey, R.P. Muraro, R.P. Norberg, M. Rohmani, F.M. Roka, and R.E. Rouse. 2006. An economic assessment of the future prospects for the Florida citrus industry. 6 May 2011 <http://www.fred.ifas.ufl.edu/Florida/ juice/pubs/EconAssessment.pdf>.

Taylor, S.E. 1996. Effect of rate and application timing of glyphosate to control sicklepod and other problem weeds of the Mississippi Delta. MS Diss.,University of Arkansas, Fayettville.

U.S. Department of Agriculture. 2006. Situation and outlook for citrus. 29 July
2011. <http://www.fas.usda.gov/htp/ Hort_Circular/2006/02-06/02-20 06\%20Citrus $\% 20$ Feature.pdf $>$.

U.S. Department of Agriculture. 2010a. Citrus: Commercial citrus inventory. 5 May 2011. <http://www.nass.usda.gov/ Statistics_by_State/Florida/Publications/ Citrus/ccipre/ccipr10.pdf>.

U.S. Department of Agriculture. 2010b. Citrus: 2009-2010 citrus summary: Production, practices and value. 5 May 2011. <http://www.nass.usda.gov/Statistics_ by_State/Florida/Publications/Citrus / cspre/cit92310.pdf>. 